2. On the Mollusca procured during the 'Lightning' and 'Porcupine' Expeditions, 1868-70. (Part VI. ${ }^{1}$ ) By J. GWYN JEFFREYs, LL.D., F.R.S., F.Z.S.

[Received February 23, 1883.]

(Plates XIX., XX.)

GASTROPODA (continued).

Family VI. Scissureldida.

1. Scissurelda crispata, Fleming.

S. crispata, Flem. Mem. Wern. Soc. vi. p. 385, pl. 6. f. 3 : B. C. iii. p. 283 , pl. vii. f. 2 ; v. p. 201 , pl. lx. f. $3,3 a, 3 b$.

'Lightning' Exp. St. 2, 5.

'Porcupine' Exp. 1869: 14, 25, 36 (var. aspera), 70.1870 : Atl. $1,2,6,9,13,16-17 a, 24,27-30$, Tangier B. (and vars. angulata and aspera); Med. 45, 50, Adventure Bank, off Rinaldo's Chair (var. aspera).

Distribution. From Spitzbergen to Sicily and Azores, and from Greenland to New England; 4-790 fms.

Fossil. Pliocene: Coralline Crag, Italy, Rhodes. Post-tertiary : Norway and Sicily.

S. angulata of Lovén and S. aspera of Philippi are varieties; the latter corresponds with my variety paucicostata. S. angulata is larger, and S. aspera more conical with stronger and fewer striæ. The height of the spire and consequent contraction of the umbilicus, as well as the number and strengtb of the riblets and spiral strix, are variable characters. The variety aspera is more peculiarly Mediterranean than the typical form.

The animal was fully described by me in the 'Annals and Magazine of Natural History' for June 1870.

2. Scissurella umbilicata ${ }^{2}$, Jeffreys. (Plate XIX. fig. 1.)

Shell forming a depressed sphere which is equally raised above and below, rather thin, semitransparent, and somewhat glossy: sculpture, none except very fine and close-set, but indistinct, lines of growth : colour white : spire slightly raised: whorls $4-5$, fattened above and sloping outwards; they rapidly enlarge, so that the last or body-whorl considerably exceeds in size the rest of the shell: slit long and central, equal in width, with upturned edges : mouth nearly circular, but somewhat angulated where it is united to the body-whorl below the peripheral keel : peristome continuous, although not free in consequence of the inner lip being attached to the shell : outer lip thin and sharp : inner lip spread on the lower

i For Part I. see P.Z. S. 1878, p. 393; for Part II. see P.Z. S. 1879, p. 553; for Part III. see P.Z.S. 1881, p. 693; for Part IV. see P.Z. S. 1881, p. 922; and for Part V. see P. Z. S. 1882, p. 656.

2 Umbilicate. 
P.Z.S.1883.PI.XIX
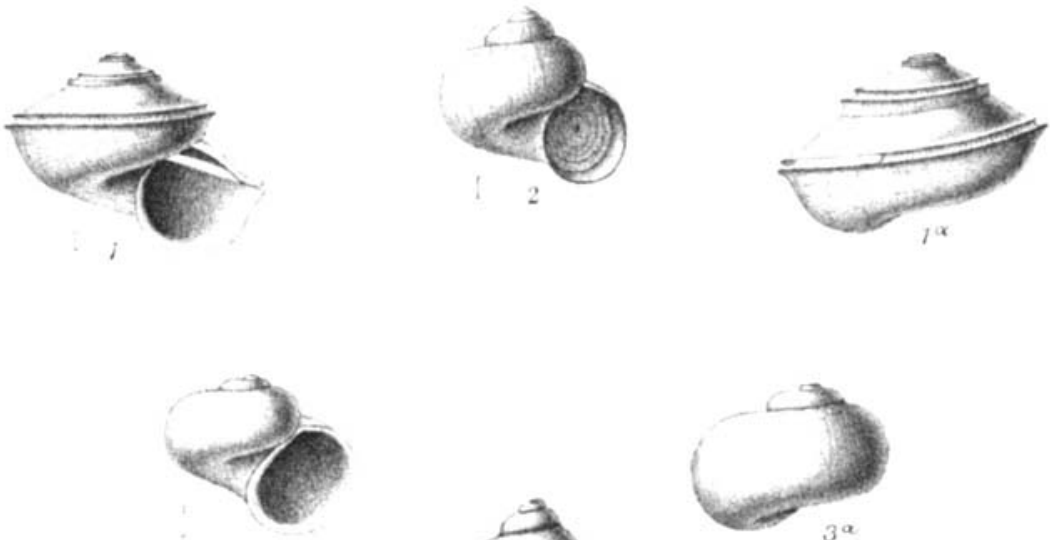

3
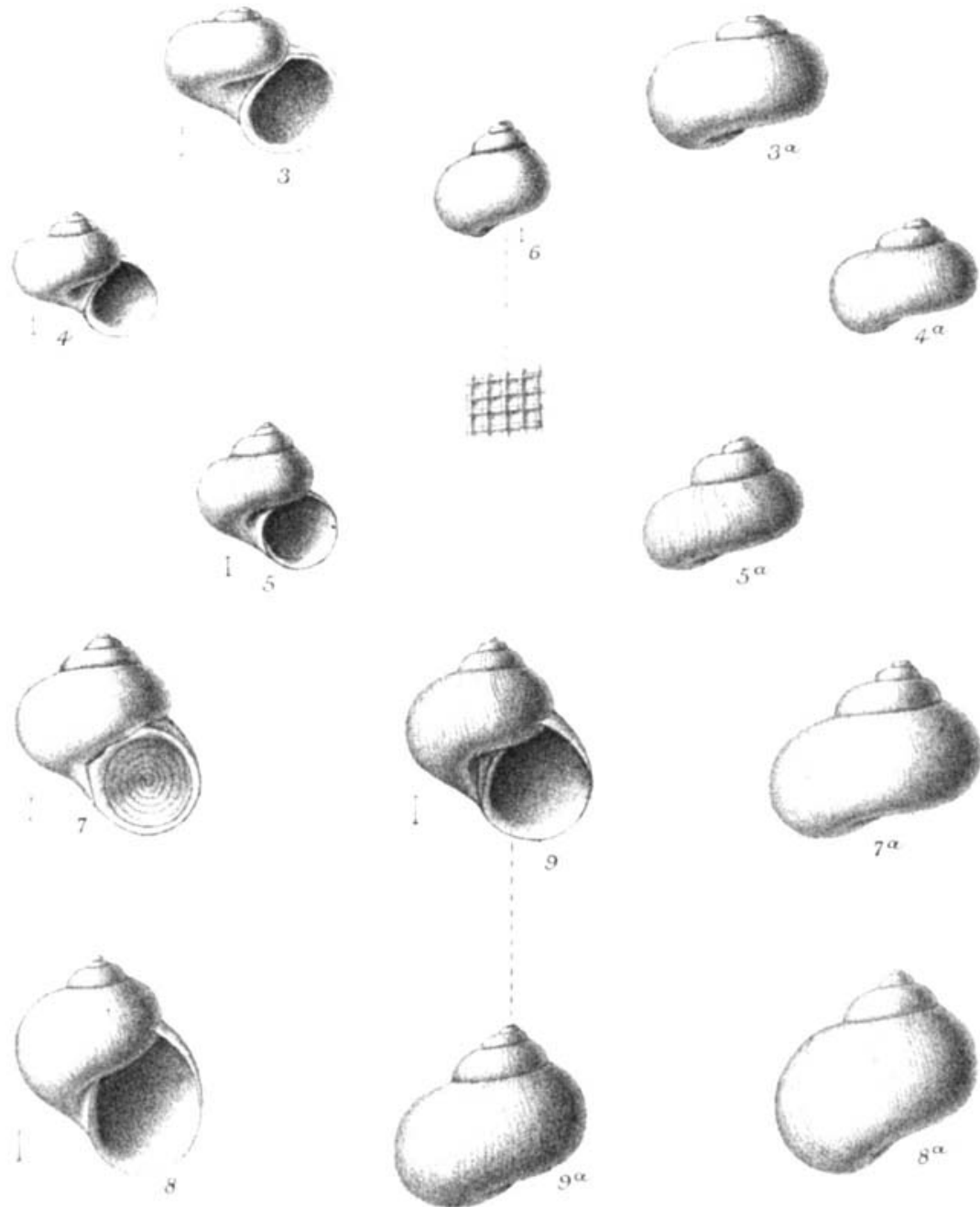

\#

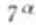

C.Berjeau delot hth. 


\section{P Z.S.1883.PIXX.}
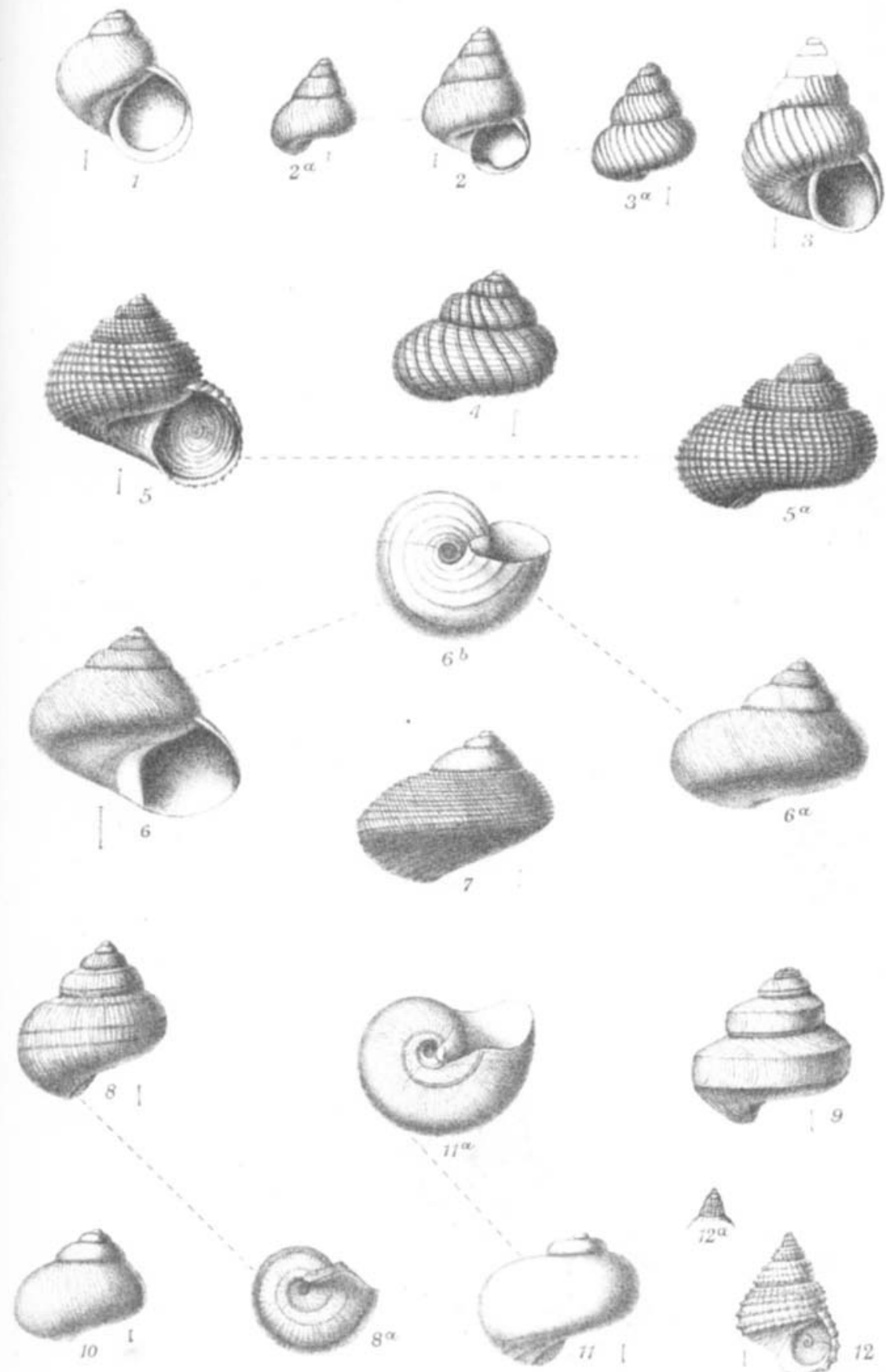

急 
part of the body-whorl : umbilicus rather large, funnel-shaped, and deep : operculum not observed, the specimens now described being dead. L. $0 \cdot 1$, B. $0 \cdot 1$.

'Porcupine' Exp. 1870 : Atl. St. 16, 17, 17a. Several specimens, more or less perfect.

This differs from any other species known to me in being devoid of sculpture, and in having a conspicuous umbilicus.

3. Scissurella costata, d'Orbigny.

S. costata, d'Orb. Mém. Soc. d'hist. nat. de Paris, i. p. 344, t. xxiii. f. 2.

'Porcupine' Exp. 1870 : Atl. St. Tangier B.

Distribution. Throughout the Mediterranean and Adriatic, Madeira (Watson), Teneriffe (McAndrew) ; 0-11 fms.

Fossil. Pliocene: Italy, Rhodes.

S. plicata and S. striatula, Philippi, besides several obsolete synonyms.

S. lavigata of d'Orbigny is apparently a variety.

Family VII. TrochIDE.

1. Mölleria costulata, Möller.

Margarita? costulata, Möll. Ind. Moll. Grönl. p. 8.

Molleria costulata, B. C. iii. p. 291 : G. O. Sars, Moll. reg. arct. norv. p. 127 , t. 9 . f. 8 , $a-c$.

'Lightning' Exp., St. 2.

'Porcupine' Exp. 1870: Atl. 17.

Distribution. Arctic seas in both hemispheres, eastern coasts of N. America, Bay of Biscay ('Travailleur' Exp. 1880), St. Thomas, W. Indies (Verkrüzen) ; 0-150 fms.

Fossil. Post-tertiary: Scandinavia, Shetland, Scotland, co. Antrim, Canada ; 0-460 ft.

This genus is distinguishable from Cyclostrema by having a double inside lip or a ledge to receive the strong calcareous operculum. The sculpture also is peculiar. I described the animal of $M$. costulata in the 'Annals and Magazine of Natural History' for March 1877. The odontophore has been figured by Friele. lippi.

Margarita minutissima of Mighels, and Skenea molleri of Phi-

2. Mölleria levigata, Jeffreys.

Molleria lavigata (Jeffr.), Friele, Bidrag til Vestlandets Molluskfauna (Vid. Forh. 1875), p. 4 ; separate copy.

Cyclostrema lavigatum, G. O. Sars, Moll. reg. arct. norv. p. 130, t. 21 . f. $2, a-b$.

'Lightning' Exp., St. 5, 6.

Distribution. Finmark (G. O. Sars), Bergen coast (Friele, Norman, and J. G.J.), Shetland (J.G.J.) ; 20-250 fms.

Fossil. Pliocene : Sicily.

Cyclostrema basistriatum of Brugnone; but in a copy of his 
paper, which he kindly sent me, he altered the specific name to curvistriatum.

I had overlooked a specimen of this little shell among my Shetland dredgings. The peristome and curved striæ on the base show that it belongs to Mölleria and not to Cyclostrema.

1. Cyclostrema serpuloüdes, Montagu.

Helix serpuloides, Mont. Test. Brit. Suppl. p. 147, t. 21 . f. 3. f. 3.

C. serpuloz̈des, B. C. iii. p. 290 , pl, vii. f. 3 ; v. p. 201 , pl. lxi.

'Lightning' Exp., St. 4.

'Porcupine, Exp. 1880 : Atl. Vigo B. fms.

Distribution. Bodö in Norway to Sicily and the Adriatic ; 0-80

Fossil. Pliocene : Calabria. Post-tertiary : Scandinavia and W. Scotland.

Skenea divisa of Fleming, and Delphinula lavis of Philippi.

2. Cyclostrema areolatum, G. O. Sars.

C. areolatum, G. O. Sars, Moll. reg. arct. norv. p. 345, t. 34 . f. $6, a-d$.

'Lightning' Exp. St. 2. Two specimens.

Distribution. Norway (G. O. Sars).

Some years before the publication by Prof. G. O. Sars I had sent a description of this species, under the name of C. sculptum, to the late Sir Wyville Thomson, at his request, for the purpose of having the Mollusca of the 'Lightning' Expedition separately published. That was not done; and I mention it, because my MS. must not now be regarded. 'This pretty little shell might be taken for the very young of Trochus gronlandicus; but the peristome is complete.

3. Cyclostrema rugulosum, Jeffreys.

C. rugulosum (Jeffr.), G. O. Sars, Moll. reg. arct. norv. p. 129, t. 2]. f. 1, $a-b$.

'Lightning' Exp. St. 5 .

'Porcupine' Exp. 1870 : Atl. 9.

Distribution. Lofoten I. and W. Norway, Messina (Granata), N. England (Verrill) ; 80-375 fms.

Fossil. Pliocene: Messina (Seguenza)!

More globular and smaller than $C$. serpuloüdes.

4. Cyclostrema basistriatum, Jeffreys.

C. (Molleria) basistriatum, Brugn. Misc. Malach. pars ii. 1876, p. 17, f. 24 .

C. basistriatum, Jeffr. Ann. \& Mag. N.H. 1877, p. 234 : G. O.

Sars, Moll. reg. arct. norv. p. 128, t. 8. f. 8, $a-c$.

'Porcupine' Exp. 1869 : St. 89. 1870 : Atl. 16, 17, 17a.

Distribution. Spitzbergen to Dröbak, 'Valorous' Exp.; 501333 fms. 
Fossil. Pliocene: Ficarazi (Brugnone).

The shell is usually striated on the base only; but some specimens are striated on the upper whorls also, and others are occasionally striated throughout. For this reason I should have preferred another specific name; but Weinkauff, in his excellent and useful Catalogue of the Shells of the European Seas, as well as Friele, in his 'Oversigt over de $i$ Bergen omegn forekomenender skaldægter Mollusker,' adopted my MS. name some years before Brugnone described another shell as fossil under the same name. See Molleria levigata antè. The odontophore is figured by Friele.

C. profundum of Friele, from specimens striated throughout.

5. Cyclostrema cutlerianum, Clark.

Skenea cutleriana, Clark in Ann. \& Mag. N. H. (n. ser.) iv. p. 424 .

C. cutlerianum, B. C. iii. p. 287 ; v. p. 201 , pl. lxi. f. 1.

'Porcupine' Exp. 1870: Atl. St. Vigo B.

Distribution. Skye, S. England, Guernsey, Naples and Sicily; $15-40$ fms.

Fossil. Pliocene : Calabria and Sicily. Post-tertiary : Montreal (Dawson).

6. Cyclostrema nitens, Philippi.

Delphinula nitens, Phil. Moll. Sic. ii. p. 146, t. xxv. f. 4.

C. nitens, B. C. iii. p. 289 ; v. p. 201 , pl. lxi. f. 2 .

'Porcupine' Exp. 1870 : Med. St. off Rinaldo's Chair.

Distribution. Shetland to the Agean; 0-9l3 fms.

Fossil. Pliocene : Calabria and Sicily. Post-tertiary: Co.Antrim. Margarita pusilla, Jeffreys, 1848; var. Slcenea? lavis, Forbes and Hanley.

7. Cyclostrema trochoïnes, Jeffreys.

C. trochoides (Jeffr.), Friele, Bidr. Vestl. Molluskf. (Vid. Forh. 1875) p. 2, separate copy ; G. O. Sars, Moll. reg. arct. norv. p. 131, t. 8. f. $9, a-c$.

'Porcupine' Exp. 1870 : Atl. St. 17 a (living).

Distribution. Finmark and W. Norway, Bay of Biscay ('Travailleur' Exp. 1880), Palermo (Monterosato), N. England (Verrill); $10-372$ fms.

The umbilicus is sometimes encircled by one or more strong spiral striæ.

Var. $C$. peterseni, Friele. He has figured the adontophore.

8. Cyclostrema tenerum ${ }^{1}$, Jeffreys. (Plate XIX. fig. 2.).

SHELr. globosely conical, thin and delicate, semitransparent, lustreless : sculpture extremely fine and close-set but nearly microscopic spiral striæ, which are wanting on the base and replaced by a rugose or fretted appearance : colour pale yellowish-white, with a 
DR. GWYN JEFFREYS ON THE MOLLUSCA OF THE [Mar. 6,

faint tinge of green : spire considerably raised: whorls 4 , rounded and convex; the last occupies two thirds of the spire; the first is very small and abruptly twisted : suture very deep : mouth circular, with a thin and slightly expanded lip: umbilicus rather narrow but deep : operculum thin, having 6 or 7 whorls, the two outermost being proportionally much larger than the inner whorls and divided by raised ledges. L. $0 \cdot 075$, B. $0 \cdot 1$.

'Porcupine' Exp. 1869: St. 16. A single but living specimen.

The shell is more conical and thinner than C. trochoïdes; the spire is more raised, and the sculpture very different.

9. Cyclostrema valvatoides ${ }^{2}$, Jeffreys. (Plate XIX. fig. 3.)

SHELl obliquely helical, rather solid, opaque and glossy: sculpture none except slight and irregular lines of growth: colour whitish, with a faint tinge of yellow : spire depressed: whorls 4, rounded and swollen; the last expands outwards, and occupies about three fourths of the spire; the top whorls are flattened: suture deep : mouth very large and circular, with a short and obtuse angle at the upper corner; the lip is considerably reflected or folded back: umbilicus small and shallow. L. $0 \cdot 075$, B. $0 \cdot 125$.

'Porcupine' Exp. 1870: Atl. St. 17a. A single but perfect specimen.

The description shows that this is a very distinct and peculiar species. It certainly belongs to the present genus, although having the aspect of a Valvata.

\section{Cyclostrema simile ${ }^{2}$, Jeffreys. (Plate XIX. fig. 4.)}

SHELL orbicular, compressed above and below, rather thin, opaque, but glossy; sculpture none: colour whitish: spire much depressed : whorls $4 \frac{1}{2}$, rounded and convex; the last occupies about one half of the shell; first whorl spiral: suture wide and deep: mouth nearly circular, but slightly truncate on the inner side ; edges thin : umbilicus open and deep, exposing part of the penultimate whorl. L. $0 \cdot 025$, B. $0 \cdot 05$.

'Porcupine' Exp. 1870 : Atl. St. 16, 17a. Three specimens.

Smaller than O.valvatoiddes, but apparently full-grown; the spire is more depressed, the suture deeper, the last whorl not so disproportionately large, the mouth smaller with simple and not reflected edges, and the umbilicus is much more open.

\section{Cyclostrema affine ${ }^{3}$, Jeffreys. (Plate XIX, fig 5.)}

SHELL resembling a species of the Margarita section of Trochus, turreted, rather thin, semitransparent and glossy: sculpture none: colour clear white : spire raised : whorls 4, swollen; the last occupies about two thirds of the shell; first whorl bulbous : suture narrow but deep : mouth slightly angulated on the upper side, where it

' Shaped like a Valvata.

${ }^{2}$ Similar, i. e. to C. valvatoïdes.

${ }^{3}$ Allied, i. e. to species of Trochus. 
joins the periphery; edges thin: umbilicus contracted and small. L. $0 \cdot 075$, B. $0 \cdot 075$.

'Porcupine' Exp. 1870 : Atl. St. 16, 17, 17a, 27, 28. Specimens very numerous.

Distribution. Josephine Bank, Bay of Biscay ('Travailleur' Exp. 1881), Palermo (Monterosato); $103-913 \mathrm{fms}$.

Differs from $C$. simile in shape, as well as in the raised spire and narrow umbilicus.

12. Cyclostrema bithynö̈nes ${ }^{2}$, Jeffreys. (Plate XIX. fig.6.)

Shexc oval, thin, having a somewhat frosty appearance, opaque and lustreless: sculpture, numerous, close-set, and delicate spiral strix, which are only perceptible under a microscope: colour whitish: spire raised; whorls $3 \frac{\mathrm{I}}{2}$; the last is tumid and takes up three fourths of the shell; apex slightly twisted: suture deep: mouth roundish-oval; the peristome is not disjoined from the pillar, although complete and partly attached to it: umbilicus very small. L. $0 \cdot 065$, B. 0.05 .

'Porcupine' Exp. 1870 : Atl. St. 16. A single specimen.

13. Cyclostrema spheroïnes, (spharoidea) S. V. Wood.

Turbo spheroidea, S. V. Wood, Ann. \& Mag. N. H. 1842, p. 533, pl. v. f. 3 .

'Porcupine' Exp. 1870: Atl. St. 24, 26-28, 36, Tangier B. Several specimens.

Distribution. Bay of Biscay ('Travailleur' Exp. 188I).

Fossil. Pliocene : Coralline Crag, Sutton.

Although minute, this is a very remarkable and beautiful species. It appears to be more scarce as a fossil than as recent or living. The operculum has not yet been observed.

\section{Genus Tharsis ${ }^{2}$, Jeffreys.}

Sheld globular, solid, and glossy: peristome circular and continuous, but attached to the pillar on that side : base closed by a pad or thick testaceons layer in the adult, perforated in the young: operculum chitinous or horny, and multispiral.

This genus differs from Cyclostrema in the peristome being, although continuous, not free or detached from the rest of the shell, and in the umbilicus being closed instead of open in the adult. I do not consider it (as Seguenza supposed) Oxystele of Philippi, which is typified by Trochus merula ; in that genus the peristome is not continuous, and the pillar is sharply pointed or angulated at its base.

Tharsis romettensis, Seguenza. (Plate XIX. fig. 7.)

Oxystele romettensis (Seg.), Granata-Grillo, Descr. de qu. esp. nouv, ou peu conn. 1877, p. 7 .

'Porcupine' Exp. 1870: Atl. St. 16, 17, 17a, 24; Med. 45.

${ }^{1}$ Shaped like a species of Bithynia.

2 One of the many synonyms of Cyprus. 
Distribution. Str. Messina (Granata-Grillo), Palermo (Monterosato), Tunisian coast ('Shearwater' Exp.), Bay of Biscay ('Travailletr' Exp. 1880), G. Marseilles ('Travailleur' Exp. 1881); 1081093 fms.

Fossil. Pliocene: Calabria and Sicily (Seguenza).

$$
\text { Genus GaNE'sA ', Jeffreys. }
$$

SHezx shaped like a Natica, thin: peristome continuous, free and separate in the young, but united to the periphery in the adult: spire having an oblique axis: base perforated, not umbilicate : operculum horny, multispiral.

Differs from Tharsis in the obliquity of the spire and perforation of the base at every stage of growth.

1. Ganesa pruinosa ${ }^{2}$, Jeffreys. (Plate XIX. fig. 8.)

Sheld nearly spherical, of a delicate texture, semitramsparent, lustreless and having a remarkably frosted appearance: sculpture very peculiar, and consisting of minute and numerous, but irregularly disposed, white tubercles, which are partly embedded in the substance of the shell; one specimen is marked by slight spiral lines below the suture of each whorl: colour dull white: spire raised: whorls 4, swollen; the last exceeds in size three fourths of the whole shell; apex prominent and twisted: suture deep : mouth nearly circular, angulated at the upper corner: base oblique, having a small and narrow umbilical chink: operculum glossy, having the edges of the whorls raised. L. $0 \cdot 175$, B. $0 \cdot 15$.

'Porcupine' Exp. 1869 : St. 23. 1870: Atl. 17, 17a. A few specimens.

\section{Ganesa nitidiuscula ${ }^{3}$, Jeffreys. (Plate XIX. fig. 9.)}

SHELL differs from G. pruinosa in being exactly globular, opaque, and rather glossy; the sculpture consists of flexuous but slight and remote raised strixe in the line of growth; the last or body-whorl is not so disproportionately large ; the apex of the spire is depressed ; the mouth is angulated both above and below; and the umbilical chink is channelled. L. $0 \cdot 125$, B. $0 \cdot 125$.

'Porcupine' Exp. 1869 : St. 23a. 1870: Atl. 17.

Distribution. Between the Hebrides and Faroes ('Triton' cruise); 570 fms. Very rare.

$$
\text { Genus Craculus }{ }^{4} \text {, Jeffreys. }
$$

Animal not known.

SheLI, coin-shaped or forming a circular compressed disk, slightly nacreous or pearly : mouth quadrangular, with a discontinuous peristome: umbilicus very wide : operculum multispiral, as in other genera of Trochide.

Originally proposed by me as a section of Trochus, but since adopted by Monterosato as a generic name.

\footnotetext{
1 The Hindoo god of science.

Somewhat shining.

${ }^{2}$ Frosted.

4 A little circle.
} 
Craculus striatus, Philippi.

Valvata striata, Phil. En. Moll. Sic. i. (1836) p. 147, t. ix. f: $3, x-c$.

Trochus duminyi, B. C. iii. p. 3 I 5 ; v. p. 203, pl. lxii. f. 5.

'Porcupine' Exp. 1869 : Donegal B.

Distribution. Bundoran in Donegal Bay, Atlantic coasts of France and Spain, Mediterranean, and Atlantic ; 20-50 fms.

Fossil. Pliocene : Coralline Crag and Italy.

Solarium philippii, Cantraine, and Delphinula duminyi, Requien.

A. Margarita, Gray.

1. Trochus fulgidus ${ }^{1}$, Jeffreys. (Plate XX. fig. 1.)

Shell globoso-conical, rather thin, transparent, and of a bright lustre: sculpture, only some very fine and scratch-like spiral striæ round the base : colour clear white : spire raised : whorls 4, convex, somewhat flattened below the suture; the last occupies four fifths of the shell; apex depressed, and regularly spiral: suture rather deep: mouth circular, incurved above; the peristome is not continuous or complete, but similar to that of other species in the present genus; umbilicus narrow and deep ; operculum filmy, multispiral, with obscure lines to distinguish the whorls. L. $0 \cdot 1$, B. $0 \cdot 085$.

'Porcupine' Exp. 1870 : Atl. St. 9. A single but living specimen.

2. Trochus minutulus ${ }^{2}$, Jeffreys. (Plate XX. fig. 2.)

Shell pyramidal, rather solid for its minute size, opaque, and polished: sculpture none: colour white, with a yellowish tinge: spire raised : whorls 6 , moderately convex but compressed, regularly enlarging; the last is slightly keeled on the periphery, and occupies about two fifths of the shell; apex blunt : suture distinct and rather deep : mouth representing an arc of two thirds of a circle, incurved just below the periphery, and somewhat expanded below : umbilicus sunken, with a small and deep perforation in the middle. L. 0.0625, B. $0 \cdot 05$.

'Porcupine' Exp. 1880: Atl. St. 16, 17a. A few specimens.

Fossil. Pliocene: Messina (Seguenza, as Margarita minima, MS.)! As this name, however, has not been published, nor (as I believe) been known to any but Seguenza and myself, I venture to change it for an equally classical name which has not the objection of being comparative in point of size. Perhaps hereafter a still more minute species may be discovered, and thus the name minima would become inappropriate.

3. Trochus laminarum ${ }^{3}$, Jeffreys. (Plate XX. fig. 3.)

SHELL conical, rather thin, semitransparent, and lustreless : sculpture, numerous thin and delicate, but jagged and irregular curved laminæ in the line of growth, which do not extend to the umbilicus;
1 Glittering.
? Very suall.
- Covered with thin plates. 
there are about 40 on the last whorl, some of them double ; the interstices are quite smooth: colour liyht yellowish-brown: spire raised: whorls 6 , convex and rounded; the last is equal to about two fifth of the spire; apex twisted: suture distinct: mouth nearly circular; outer lip thin, but thicker and expanded at the base and partly folded over the umbilical perforation: umbilicus somewhat concave, with a small perforation. L. $0 \cdot 15$, B. $0 \cdot 1$.

'Porcupine' Exp. 1870: Atl. St. 16, 17a. Two specimens, one imperfect and the other not full-grown.

\section{Trochus cancellatus ${ }^{1}$, Jeffreys. (Plate XX. fig. 4.)}

Shell forming a depressed cone, rather thin, opaque, and lustreless: sculpture, oblique laminar ribs in the line of growth, which are crossed by as many but slighter spiral striæ; there are about 20 ribs and striæ on the last whorl; this sculpture covers the base, but the striæ are wanting on the apex: colour pale yellowish-brown: spire rather depressed: whorls 5-6, convex; the last occupies three fifths of the shell; apex regular and compressed : mouth more round than oval, angulated above and below on the inner side: outer lip somewhat expanded and thickened: inner lip nearly straight, attached to the pillar below the periphery: umbilicus rather narrow, with a deep perforation which exposes the inner whorls. L. $0 \cdot 1$, B. $0 \cdot 15$.

'Porcupine' Exp. 1870 : Atl. St. 16. A single specimen.

Distribution. Josephine Bank ('Josephine' Exp.); 340-430 fms.

This and the following five species, or some of them, belong to the genus Macharoplax of Friele, which chiefly depends on the form of the radula or odontophore.

\section{Trochus cinereus, Couthouy.}

Turbo cinereus, Couth, in Boston Journ. Nat. Hist, vol. ii. p. 99 , pl. 3. f. 9 (1839).

Trochus cinereus, B. C. iii. p. 304 ; v. p. 202.

'Porcupine' Exp. 1869 : St. 14. A young and dead specimen, but apparently recent.

Distribution. Aretic seas in both hemispheres, from Spitzbergen and Iceland to Floroe near Bergen and the Siberian coast, and from W. and E. Greenland to C. Cod, and Behring Str. to Sitka ; 5-150 fms.

Fossil. Post-tertiary : Scandinavia, Shetland, E. and W. Scotland, Ireland, N. America, and Sicily?; $0-460 \mathrm{ft}$.

Margarita striata of Broderip and Sowerby (1828-29), but not Trochus striatus of Linné, possibly $M$. arctica of Leach (1819) and $T$. leachii of Philippi, and $M$. sordida of Hancock. As fossil, perhaps T. granatelli of Calcara. Leach's description is indeterminable, viz.:- " $M$. purpurascente carnea tenuiter striolata, operculo testaceo."

The animal has been described by me (in the 'Annals and Magazine of Nat. Hist.' for March 1877), and the odontophore by Friele.

\footnotetext{
1 Cross-barred.
} 
6. Trochus obscurus, Couthouy.

Turbo obscurus, Conth. in Bost. Journ. N. H. ii. p. 100, pl. 3. f. 12 .

'Lightning' Exp. St. 2. Fragment.

'Porcupine' Exp. 1869: St. 51. Three living specimens.

Distribution. Spitzbergen, Novaia Zemblia, and Jan Mayen I. to Upper Norway, Aleutian I. and Sitka, G. St. Lawrence, Nova Scotia, and N. England; 0-430 fms.

Fossil. Post-tertiary: Novaia Zemblia (Leche).

I consider Margarita albula of Gould and M. bella of Verkrüzen varieties of the present species.

7. Trochus Grendandicus, Chemnitz.

T. groenlandicus, Chemn. Conch. Cab. v. p. 108, t. 171.f. 1671: B. C. iii. p. 298 ; v. p. 202 , pl. lxi. f. 5 .

'Lightning' Exp. St. 7. Fragments.

'Porcupine' Exp.: N. Channel.

Distribution. Spitzbergen, Jan Mayen I., Novaia Zemblia, Siberian coast, Iceland, Faroes, Norway, Shetland and Orkneys, Scotland, E. and W. Greenland, and Canada southwards to C. Cod; $0-150$ fms.

Fossil. Post-tertiary : Scandinavia, E. and W. Scotland, Ireland; $0-460 \mathrm{ft}$.

Trochus cinerarius of Fabricius but not of Linné, Tr. Fabricii of Philippi, Turbo incarnatus of Conthouy, Turbo carneus of R. T. Lowe, Margarita undulata of G. B. Sowerby, and Tr. inflatus of Brown. Possibly Turbo fuscus of O. F. Müller and Maryarita striata of Leach. The sculpture in this, as well as in the last species, is very variable.

8. Trochus cinctus, Philippi.

T. cinctus, Ph. En. Moll. Sic. (1836) i. p. 185, t. x. f. 20, $20 a$.

T. amabilis, B. C. iii. p. 300 ; v. pl. lxi. f. 6 .

'Lightning' Exp. St. 2.

'Porcupine' Exp. 1869: 3, 14, 15, 23a, 36, 51, 61, 89. 1870 : Atl. 1, 2, 3, 3a, 9, 13, 14, 24, 25, off C. Sagres, 26-30. And variety affinis.

Distribution. Shetland, W. Norway, var. affinis (Friele and G. $O$. Sars), Bay of Biscay ('Travailleur' Exp. 1881-82), Azores ('Josephine' Exp.) ; 85-673 fms.

Fossil. Pliocene: Coralline Crag, Monte Mario, Calabria, and Sicily.

Solariella (afterwards Margarita?) maculata of S. V. Wood, and Solarium calandrelli of Conti. I do not consider Turbo moniliferus of Nyst (not of J. Sowerby), afterwards his Solarium turbinoides, from the "sables noirs" of Antwerp, the same as the present species. The shape and sculpture are very different As recent it is my Trochus amatilis; the variety affinis is Macharoplax hidalgoi of Fischer. T. affinis of D'Eichwald is a very different species. 
This lovely shell is extremely variable in respect of the height of the spire and the consequent contraction or dilatation of the umbilicus, as well as with regard to the sculpture. I have now examined between 200 and 300 specimens of different sizes and ages, and can scarcely find any two of them exactly alike. A remarkable variety which I have named affinis, and at one time believed to be a distinct species, is figured in Plate XX. fig. 5. It is finely and closely reticulated; the whorls are rounded and show no trace of angularity; and the umbilicus is not encircled by a keel. The typical or fossil form is usually marked with an irregular row of reddish spots, which are not observable in living specimens. Owing to the variability and the want of sufficient means of comparison, I could not identify our Crag shell with the recent species; but the opportunity lately afforded me by my friend Prof. Seguenza of inspecting his extensive and most interesting collection of Reggio fossils has now enabled me to connect them.

9. Trochus otror, Philippi.

T. ottoi, Phil. Moll. Sic. ii. p. 227, t. xxviii. f. 9.

'Porcupine' Exp. 1869 : St. 23 ; fragments. 1870: Atl. 16, 17, $17 a$, off C. Espichel.

Distribution. Josephine Bank, Bay of Biscay ('Travailleur' Exp.), between the Hebrides and Faroes ('Triton' cruise), Mediterranean, ('Washington' Exp. 1881), St. Thomas, Danish W. Indies ('Challenger' Exp.), N. England; $115-1044$ fms.

Fossil. Pliocene : Calabria and Sicily.

Margarita regalis of Verrill and Smith, Trochus (Margarita) rhysus and T. (Marg.) cegleis of Watson, and T. vaillanti of Fischer.

The American resemble the fossil specimens more closely than those from the European seas ; but the species shows considerable variability as regards the sculpture and umbilicus. The apex or primary whorls ought to be examined in this and all other turbinated Gasteropods as affording a good criterion of distinction.

So many species of this peculiar and beautiful type have been described by Mr. Watson from the 'Challenger' Expedition, that they might constitute a distinct section of Trochus equal to that of Margarita.

\section{B. Oxystele, Philippi.}

10. Trochus euspira, Dall. (Plate XX. fig. 6.)

Margarita? euspira, Dall, Bull. Mus. Comp. Zoöl. 1881, p. 44.

'Porcupine' Exp. 1870: Atl. St. 16, 17, 17a. Specimens numerous, but dead and few quite perfect.

Distribution. Culebra I., Danish W. Indies ('Challenger' Exp.), G. Mexico ('Blake' Exp.); 390-805 fms.

The diameter of my largest specimen is about three tenths of an inch or 9 millimètres. This pretty shell is extremely variable as regards the height of the spire and the sculpture. Some specimens are quite smooth; others are spirally striated throughout, or on the 
body-whorl only, or on the upper whorls, or round the umbilicus ; some (var. coronata) have a row of beads below the suture. In all my specimens there is a minute tubercle on the broad and fretted pillar near its base, but not at its base as stated by $\mathrm{Mr}$. Dall in the description of his specimens. The young are always umbilicate.

Philippi's description of his genus Oxystele in the 'Handbuch der Conchyliologie und Malacozoologie,' 1853, p. 210, is as follows:-

"Oxystele, Ph. 1847, Zeitschr.f. Malak. p. 19". Das Gehäuse ist conoidisch, glatt, ungenabelt, anstatt des Nabels eine dünne porzellanartige Ausbreitung der Spindel; diese ist platt, schneidend, geht allmählig in die dünne äussere Lippe über. Tr. merula." 'These characters exactly suit the present species. Mr. Dall proposed a new sectional name Bathymophila.

The manuscript name which I had given to the present species was nitens; but that name had been already used for an Australian species.

11. Trochus suturalis, Philippi.

T. suturalis, Phil. En. Moll. Sic. i. p. 185 , t. x. f. $23,23 a$; ii. p. 156 .

'Porcupine' Exp. 1869 : St. 36. 1870 : Atl. 3, 3a, 6, 8, 9, Vigo B., 13, 24-28a, 36; Med. 45, Rasel Amoush, G. Tunis.

Distribution. Bay of Biscay and G. Marseilles ('Travailleur' Exp.); 174-1025 fms.

Fossil. Pliocene: Monte Mario, Calabria, and Sicily.

Animal pale brownish-yellow: tentacles conical, edged on each side with a purplish-brown line : eyes black, conspicuous, placed as usual in the genus : foot thick, fringed with white conical papillæ, 4 on each side; no ocelli or eye-spots.

The small fossil originally described and figured by Philippi did scant justice to this beautiful shell, which has now been discovered to be still living. My finest specimens are about seven tenths of an inch in length and breadth; the colour is cream with the tint of a blush rose; and the sculpture is variable as regards the beaded rows of striæ. Young specimens have a deep umbilicus which is enclosed within a sharp ridge. The callus which covers the umbilicus in the adult is proportionally thinner than in the last species.

$T$. folini of Fischer is a variety of this species.

\section{Trochocochlea, Klein.}

\section{Trochus lineatus, Da Costa.}

Turbo lineatus, Da Costa, Brit. Conch. p. 100, t. vi. f. 7.

Trochus lineatus, B. C. iii. p. 317 ; v. p. 203, pl. lxii. f. 9.

'Porcupine' Exp. 1869 : St. Donegal B. 1870 : Atl. Vigo B.

Distribution. N. Ireland and Anglesea to Mogador, the Ægean, Adriatic, Canaries (d'Orbigny)?; $0-20$ fms. My friend $\mathrm{Mr}$. Watson kindly sent me from Madeira specimens of an allię species,

$$
1 \text { "ógús scharf, orín } \eta \text { Säule." }
$$


having a broad and flattened base, which he considered the present species.

Fossil. Pliocene : Leghorn (Appelius). Post-tertiary : Cumbrae (Robertson), Selsea (A. Bell).

Trochus crassus of Pulteney, whose $T$. lineatus is the young; a variet.y is Monodonta articulata, Lamarck, $M$. draparnaudi, Payraudeau, $M$. punctulata, de Blainville (not of Lamarck), M. sitis, Récluz (young), and Turbo corcyrensis, Stossich (young). Not Trochus lineatus of Lamarck, which is a Senegalese species.

The young are umbilicate, as in the last and other species of this genus.

13. Trochus turbinatus, Born.

T. turbinatus, Born. Mus. Cæs. Vind. Test. 1778, p. 340 ; id. 1780, t. 12. f. 5,6 .

' Porcupine' Exp. 1870 : Med. St. Algesiras B.

Distribution. Charente-Inférieure (Beltrémieux), throughout the Mediterranean and Adriatic, Canaries (Lister and d'Orbigny); 0-2 fins.

Fossil. Pliocene : Italy. Post-tertiary: S. France.

This species, which is so peculiar to the Mediterranean and Adriatic, is also T. tessulatus of Born, T. tessellatus of Gmelin, Monodonta fragaroides of Lamarck, $M$. olivieri of Payraudeau, and $T$. fragarioides of Philippi, a variety being his $T$. mutabilis.

Perhaps T. lineatus may be the same species. The publications of Da Costa and Born were contemporaneous. Both species, if distinct, are variable; and there appear to be intermediate gradations.

\section{Gibmula, Risso.}

14. Trochus magus, Linné.

f 1 .

T. magus, L. S. N. p. 1228 : B. C. iii. p. 305 ; v. p. 203, pl. Ixii.

'Porcupine' Exp. 1870: Med. Capo di Gaeta, Benzert Road, Adventure Bank.

Distribution. S.W. Sweden and Shetland to Mogador, Mediterranean, Adriatic, Canaries ; 0-40 fms.

Fossil. Pliocene : Italy, Rhodes, Cos, C. Verde I. Post-tertiary : Norway, British Isles, and Tuscany ; 0-1360 ft.

15. Trochus richard, (richardii) Payraudeau.

T. richardii, Payr. Moll. Corse (1826), p. 138, t. vii. f. 1, 2.

'Porcupine’ Exp. 1870 : Atl. St. Gibraltar B.

Distribution. Coast of Portugal and Gibraltar (McAndrew),

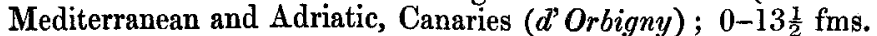

Fossil. Pliocene: Italy. Post-tertiary : S. France and Leghorn. Turbo variegatus (1813) and Phorcus margaritaceus (1826), Risso ; Trochus cinerarius, Costa, not Linné. 
16. Trochus delicatus ${ }^{1}$, Jeffreys. (Plate XX. fig. 7.)

Srell forming a depressed cone, thin, opaque, rather glossy : sculpture, on the body or last whorl only, fine and close-set spiral striæ, crossed by equally numerous curved longitudinal striæ; the spiral striæ are wanting below the suture, and are few and slight on the base; periphery bluntly keeled; umbilicus partly enclosed by a small ridge, which extends through the middle of the inside and becomes thicker outside; all the upper whorls are quite smooth: colour milk-white : whorls $4 \frac{1}{2}$, moderately convex, the last occupying about three fourths of the shell; apex somewhat twisted: mouth roundish : outer lip thin : inner lip filmy: inside slightly nacreous : umbilicus small but deep. L. $0 \cdot 075$, B. $0 \cdot 125$.

'Porcupine' Exp. 1870 : Atl. St. 24. A single and imperfect but characteristic specimen.

17. Trochus varius, Linné.

T. varius, L. S. N. p. 1229 ; Philippi, Moll. Sic. i. t. x. f. 19.

'Porcupine' Exp. 1870 : Atl. St. Vigo B.

Distribution. Gulf of Gascony (de Folin), Mediterranean and Adriatic ; 0-2 fims.

Fossil. Pliocene: Italy.

T. roissyi, Payraudeau, and T. varians, Deshayes. Var. Gibbula elata, Brusina.

18. Trochus cinerarius, Linné.

T. cinerarius, L. S. N. p. 1229 : B. C. iii. p. 309 ; v. p. 203 , pl. lxii. f. 3.

'Porcupine’ Exp. 1869 : St. L. Foyle, near Belfast. 1870 : Atl. Vigo B., 26.

Distribution. Iceland, Finmark, and Faroe I, to the Lusitanian coasts, Mogador, Mediterranean, Adriatic, and Black Sea ; 0-60 fms., inhabiting the littoral and laminarian zones.

Fossil. Pliocene: Red Crag. Post-tertiary: Scandinavia and British Isles ; 0-600 ft.

Variable in size and the comparative height of the spire.

Synonyms rather numerous. Among these or as representing varieties are Trochus lineatus of $\mathrm{Da}$ Costa, $T$. philippii of Aradas, and $T$. cineroides of Searles Wood. Not $T$. cinerarius of Born, Brocchi, Olivi, O. G. Costa, or Bellardi. My variety variegata is not Monodonta agyptiaca of Payraudeau, which is Trochus fanulum of Gmelin.

19. Trochus vilurcus, Philippi.

T. villicus, Phil. Moll. Sic. ii. p. 152, t. $x \times v$. f. 14.

‘ Porcupine' Exp. 1870 : Atl. St. Vigo B. ; Med. 50.

Distribution. Mediterranean, Black Sea, and Adriatic; $0-20 \mathrm{fms}$.

Closely allied to $T$. cinerarius, and perhaps a variety of it. It may have been included in Linné's too short description of that species.

1 Delicate. 
T. leucophceus of Philippi appears to be a variety. It is strangely omitted in his terrible list of between 400 and 500 so-called species of Trochus given in Küster's edition of the 'Conchylien-Cabinet' subsequently to the publication of Philippi's work on the Mollusca of the two Sicilies.

20. Trochus adansoni, (adansonii) Payraudeau.

T. adansonii, Payr. Moll. Corse, p. 127, t. vi. f. 7, 8. -

'Porcupine' Exp. 1870 : Med. St. Algesiras B. A small and non-umbilicate variety.

Distribution. Throughout the Mediterranean, Adriatic, and Black Sea ; $1-277 \frac{1}{2}$ fms.

Fossil. Pliocene : Coralline Crag, Italy, Archipelago, and S. Russia.

I am inclined to unite with this common species, as synonyms or varieties, $T$. turbinoides of Deshayes, $T$. sauley $i$ of d'Orbigny, $T$. adriaticus and $T$. biasoletti of Philippi, $T$. olivaceus and $T$. cinerascens of Anton, $T$. colybii of Mittré, $T$. pallidus, lyciacus, and spratti of Forbes, $T$. albidus of Weinkauff as of Gmelin, $T$. drepanensis of Brugnone (young), and other species. Brusina refers it to T. angulatus of D'Eichwald (Zool. spec. Rossiæ et Poloniæ, 1829 ); but that is a very questionable identification, and the specific name had been previously used by Quoy and Gaimard for another species of Trochus.

21. Trochus tumidus, Montagu.

T. tumidus, Mont. Test. Brit. p. 280, t. 10. f. 4: B. C. iii. p. 307 ; v. p. 203 , pl. lxii. f. 2.

'Lightning' Exp. St. 7.

'Porcupine" Exp. 1869 : St. L. Foyle. 1879: Atl. I2, Gibral$\operatorname{tar} B$.

Distribution. Iceland, Faroes, and Finmark to Egypt and the Adriatic ; 0-145 fms.

Fossil. Pliocene: Red Crag. Post-tertiary: Scandinavia, Scotland, Ireland, and Selsea ; $0-460 \mathrm{ft}$.

Var. minor. T. racketti, Payraudeau, and T. gibbosulus, Danilo and Sandri. This is the usual form in the Mediterranean, although I have the typical form from Corsica. I now believe that it cannot be (as Dillwyn supposed) $T$.nassariensis of Chemnitz or $T$. patholatus of Gmelin, which was said to have derived the first specific name from the Nassau Islands in the Indian Ocean. The fry was figured by Walker as $T$. fuscus, and described by Macgillivray as Skenea serpuloides.

22. Trochus umbilicatus, Montagu.

T. umbilicatus, Mont. Test. Brit. p. 286 : B. C. iii. p. 312 ; v. p. 203 , pl. Ixii. f. $4,4 a$.

'Porcupine' Exp. 1869 : St. Donegal B. 1870 : Atl. Vigo B.

Distribution. Stornoway to Gibraltar, Mogador, G. Lyons, Algiers, G. Naples, and other parts of the Mediterranean as well as 
the Adriatic; 0-20 fms., living in the littoral and laminarian zones.

Fossil. Pliocene : Tuscany. Post-tertiary; Cumbrae, Ireland, Cheshire, Shropshire, Hants, and Dorset.

T. umbilicaris, Pennant (not Linné), T. umbilicalis, Da Costa, and other synonyms. T. oblique radiatus of Chemnitz or $T . o b$ liquatus of Gmelin is most probably $T$. divaricatus of Linné, if indeed the last-named species be distinct from the present. Should they prove to be identical, my view that the Mediterranean has no peculiar Molluscan fauna would be further confirmed. See the Report of the British Association for 1873. T. divaricatus of Gmelin is evidently Lacuna divaricata, although he gives the habitat in his usual muddled way, viz. " mari mediterraneo et groenlandico." The umbilicus is either open or closed, as in T. divaricatus. I subjoin a description of the animal of var. agathensis ( $T$. agathensis, Récluz), which has no umbilical perforation.

BoDy greyish-white or soot-coloured; closely streaked lengthwise with purplish-brown, sometimes having a yellow tinge: mantle thick, with large lobes or lappets, sulphur-coloured; the lobe on the right hand is scalloped, the other having plain edges and folded: snout thick and rather short: tentacles filiform, club-shaped at the tips, thickly covered with short cilia, and ringed with purplishbrown : eyes globular, placed on angular offsets at the outer bases of the tentacles : foot oblong, rounded or bluntly pointed at each end; sides closely tessellated or reticulated by purplish-brown lines, with occasionally a few white specks; edges fringed with numerous clavate points arranged in a single row; sole pale lemon-coloured: appendages three on each side, resembling the tentacles in shape, but somewhat shorter. Inhabits the lower part of the tide-mark throughout the Channel Isles, the ordinary or typical form occupying the higher part, and both forms (as well as an intermediate one) being found halfway. It crawls like Littorina, by an alternate wavelike motion of each side of the foot.

23. Trochus divaricatus, Linné.

T. divaricatus, L. S. N. p. 229 ; Philippi, Conch. Cab. ed. Küster, t. 29. f. 16.

- Porcupine' Exp. 1870 : Atl. St. Gibraltar B.

Distribution. Atlantic coasts of France (Petit)?, N. Spain and Portugal (McAndrew), Mediterranean, Adriatic, and Black Sea ; 0-15 fms.

Fossil. Pust-tertiary: S. France (Fischer).

The umbilicus is perforated in the young and closed in the adult.

$\boldsymbol{T}$. rarilineatus of Michaud is a variety of this species according to Monterosato.

24. Trochus tricarinifer, (tricariniferus) Searles Wood.

T. tricariniferus, S. Wood, Crag Moll. 1848, p. 132, t. xiv. f. $6, a-b$.

'Porcupine’ Exp. 1870 : Atl. St. 16. A single specimen Proc. Zool. Soc.-1883, No. VIII. 
Distribution. Josephine Bank ('Josephine' Exp.) ; 340-430 fms. Fossil. Pliocene: Coralline Crag, Sutton.

25. Trochus ditropis, Searles Wood.

T. ditropis, S. Wood, Crag Moll. p. 133, t. xiv. f. 9, $a-b$.

'Porcupine' Exp. 1870 : Med. St. Algesiras B., 50. A single specimen from each station. Umbilicus small.

- Distribution. Palermo (Monterosato); about $22 \mathrm{fms}$.

Fossil. Pliocene : Coralline Crag, Sutton.

The specimen from Algesiras Bay is sculptured spirally and coarsely, like the Crag specimens; that from Station 50 is very finely and closely striated lengthwise on the upper part of the body-whorl, besides having the same spiral striæ on the rest of the shell. Both these specimens have purplish-brown blotches. Umbilicus very small.

Not the very young of $T$. guttadauri, as might be hastily supposed. I am not disposed to refer the present species to $T$. biangulatus of D'Eichwald ('Lethæa Rossica,' iii., dernière période, p.226, esp. 199 , pl. ix.f. $15, a, b ; 1853$ ), which is very much larger than $T$. ditropis, and is described as very finely striated in an oblique direction as well as spirally or transversely, and as having a larger umbilicus.

\section{E. Ziziphinus, Leach.}

26. Trochus montacut, (montagui) W. Wood.

T. montagui, W. Wood, Ind. Test. Suppl. pl. 6. f. 43.

T. montacuti, B. C. iii. p. 320 ; v. p. 203 , pl. lxiii. f. 1 .

'Lightning' Exp. St. 5.

'Porcupine' Exp. 1869 : St. 6. 1870 : Atl. Vigo B.

Distribution. British and Belgian coasts to Malta, var. nana, coast of Tunis ('Shearwater' Exp.), Canaries (Mc.4ndrew); 795 fims.

Fossil. Pliocene: Coralline and Red Crag, Antwerp Crag?, S. France, Italy?, and Rhodes?

T. cyrnaus, Requien, T. tumidulus, Aradas, and T. parvulus, Philippi. T.turgidulus of Brocchi is more conical, the whorls are less convex, and the sculpture is finer; but the present species may be its slightly altered descendant. The nmbilicus has occasionally a small perforation.

27. Trochus striatus, Linné.

T. striatus, L. S. N. p. 1230 : B. C. iii. p. 322 ; v. p. 203 , pl. lxiii. f. 2.

'Porcupine' Exp. 1870 : Atl. St. Vigo B.; Med. Algesiras B., Adventure Bank.

Distribution. S. England, Ireland, coasts of France, Spain, Portugal, Italy, Egean and Archiprlago, Adriatic, N. Africa, Madeira, and Canaries; $0-108 \mathrm{fms}$. 
Fossil. Pliocene: Antibes, Italy, and Rhodes. Post-tertiary : S. France.

T. striatus and its varieties have many synonyms, including (from my examination of the types) $T$. gravesi of Forbes, $T$. ruscurianus of Weinkauff, T. littoralis of Brusina, and T. fraterculus of Monterosato. This common species is extremely variable as regards the height of the spire, colour, sculpture, and the comparative prominence of the basal keel. The small striæ which intersect the spiral ribs are either fine and close-set, or coarse and comparatively few in number, and sometimes are altogether wanting. $T$. unidentatus of Philippi may be another variety of the present species.

28. Trochus exasperatus, Pennant.

T. exasperatus, Penn. Brit. Zool. iv. p. 126 : B. C. iii. p. 324 ; v. p. 203 , pl. lxiii. f. 3 .

'Porcupine' Exp. 1870 : Atl. St. Vigo B., Tangier B.; Med. Algesiras B., G. Tunis.

Distribution. S. England, Ireland?, Scotland?, Atlantic coasts of France, Spain and Portugal, Mediterranean, Black Sea, Adriatic, Morocco, Canaries, Madeira, and Azores; 0-105 fms.

Fossil. Pliocene: Italy Archipelago, and Rhodes. Post-tertiary : Wexford?, Selseg, Antibes.

The opinion which $\mathbf{F e n t u r e d}$ to express in my work on British Conchology (iii. pp. 323, 325) that this species is the same as $T$. striatus, or a variety of it, has been strengthened by further observation and experience. Among the synonyms of the present species are $T$. erythroleucus, $T$. strigosus, and $T$. punctulatus of Gmelin, $T$. exiguus of Pulteney, $T$. crenulatus of Brocehi, $T$, pyramidatus of Lamarck, T. matonii of Payraudeau, and T. elegans of Blainville.

29. Troch us wiseri, Calcara.

T. wiseri, Calc. Il Maurolico, 1841, p. 31, t. iv. f. 14.

'Porcupine' Exp. 1870 : Atl. St. 24 ; Med. 55.

Distribution. Bay of Biscay ('Travailleur' Exp. 1880 and 1881), various parts of the Mediterranean (Tiberi and others); 40$540 \mathrm{fms}$.

Fossil. Pliocene: Italy.

$T$. gemmulatus of Philippi, and $T$. scabrosus of myself not of Philippi. Distinct from T. clathratus of Aradas, to which Monterosato and Seguenza formerly, but not lately, referred it. It was apparently figured in pl. vi. f. 12 by Cantraine in his unfinished 'work, 'Malacologie méditerranéenne et littorale,' 1840, but without a name.

30. Troch Us miciaris, Brocchi.

T. miliaris, Broc. Conch. foss. Subap. ij. p. 353 , t. vi. f. 1 .

$T$ millegranus, B. O. iii. p. 325 ; v. p. 204 , pl. lxiii. f. 4.

'Lightning' Exp. St. 5, 7.

'Porcupine' Exp. 1869: 1, 6, 14, 45a, 45 6, 70, 89 (dwarf), 
Little Minch. 1870 : Atl. 24, 25, off C. Sagres, 26-30, Tangier B. ; Med. Capo di Gaeta, 45, Cartagena B., 50, Benzert Roud, Adventure Bank, off Rinaldo's Chair.

Distribution. Drontheim to the Egean and Sea of Marmara, C. Verde I. (de Rochebrune); 2-205 fms.

Fossil. Miocene : Vienna Basin and Touraine? Pliocene: English and Belgian Crags, S. France, and Italy. Post-tertiary: Norway, W. Scotland, and Nice; 0-50 ft.

There are several synonyms, including $T$. granulatus of de Blainville (not Born), and T. millegranus of Philippi, who in Küster's edition of Martini and Chemnitz gave not only the latter but also $T$. miliaris as recent species, separated from each other by many pages and plates. Some specimens or varieties differ greatly in size, or they have a higher spire and are more pyramidal; others are more finely and closely sculptured; others have quite a flattened base, while one specimen has a rounded base and no keel. In a small coarsely granulated variety the apex is twisted, and might easily be taken for a distinct species. The colour is occasionally milkwhite. The fossil type or progenitor of the species is much more conical and smaller than the living species. The specific name miliaris is not appropriate, if it has reference to millet-seed; and it is not a Latin word.

\section{Trochus granulatus, Born.}

T. granulatus, Born, Ind. Mus. Cæs. Vind. 1778, p. 343 : B. C. iii. p. 327 ; v. p. 204, pl. Ixiii. f. 5.

'Porcupine' Exp. 1869 : St. 1, $45 a, 456$. 1870 : Atl. off C. Sagres; Med. Capo di Gaeta, 50, off Jijeli, 55, Benzert Road, Rasel Amoush, G. Tunis, Adventure Bank.

Distribution. British Isles, Normandy, Mediterranean, Adriatic, Mogador, Madeira, Canaries; 2-145 fms.

Fossil. Pliocene : Red and Norwich Crags, Italy, Morea, Rhodes. Post-tertiary : Ireland.

T. papillosus, Da Costa, 1778 (not S. Wood), T. fragilis, Pulteney (not Gmelin), T. tenuis, Montagu.

Variable in sculpture, which is more or less closely beaded; the spiral strize on the lower whorls are sometimes quite smooth. The - Porcupine' specimens which I had considered T. multigranus of S. Wood I now believe to be merely the present species having larger and fewer beads or tubercles: The very young shells are deeply umbilicate.

32. Trochus zizyphinus, Linné.

T. zizyphinus, L. S. N. p. 1231 : B. C. iii. p. 330 , pl. vii. f. 4 ; v. p. 204 , pl. lxiï. f. 6 .

'Lightning' Exp. St. 4, 5 .

- Porcupine' Exp. 1869 : Lough Foyle, Little Minch. 1870 : Atl. Vigo, 25, Tangier B., Gibraltar B.: Med. Benzert Road (var. conulus), Rasel Amoush. 
Distribution. Finmark and Faroes to the Morea and Egypt, Adriatic, Mogador, Madeira, Canaries ; 0-85 fms.

Fossil. Miocene: Vienna Basin, and Marne Vaticano. Pliocene: English and Belgian Crags, Italy, Rhodes. Post-tertiary: Scotland, Ireland, S. France, Leghorn.

Var. conulus. Smaller and more conical.

T. conulus, L. S. N. p. 1230 ; Forbes and Hanley, pl. Ixxiii. f. 1, 2. With every inclination to retain a linnean species, I have endeavoured, but failed, to distinguish specifically $T$. conulus from $T$. $z i z y-$ phinus. Indeed Linne admits that the former is probably a variety of the latter:- "Testa sequenti (sc. T. zizyphino) simillima ut fere varietas minima, etiam apice tuberculata, sed linea inter anfractus prominula ; color pulcherrime variegatus."

The number of synonyms is a great disgrace to naturalists. I find 23 of them, besides at least a dozen more as species described by Risso. See also 'British Conchology,' vol. iii. pp. 332 \& 333.

Extremely variable as to size, height of the spire, colour, sutural ridge and other sculpture. The apex is always more or less granulated, even in the smoothest variety or $T$. lovigatus of Philippi. Very young shells have a small umbilicus.

\section{Trochus occrdentalis, Mighels and Adams.}

Trochus occidentalis, Migh. and Ad. Proc. Boston Soc. Nat. Hist. i. p. 47, pl. iv.f. 16 : B. C. iii. p. 333 ; v. p. 204 , pl. lxxiii. f. 7 .

'Lightning' Exp. St. 2, 5.

'Porcupine' Exp. 1869 : St. 6, 25, 61, 68.

Distribution. Finmark and Faroes to the Dogger Bank, eastern coasts of North America ; 8-150 fms.

Fossil. Pliocene : English and Belgian Crags, Messina.

$T$. alabastrum, Beck ap. Lovén, and $T$. formosus, Forbes.

In elucidation of the habits of this Trochus mentioned in 'British Conchology,' iii. p. 335, Mr. Buchanan says in his paper on the air dissolved in sea-water (Proc. R. S. Edinburgh, 1877) :- “ As regards the percentage of oxygen present at different depths, it diminishes from the surface to a depth of 300 fathoms, and increases from that point to lower depths." The odontophore of this and other Scandinavian species has been figured by Friele.

I have also fragments of two or three species of this section, besides very young specimens of other species of Trochus, from the - Porcupine" Expeditions, none of which I have been able to identify

- with any known species.

Olivia otaviana, Cantraine.

O. otaviana, Cantr. Diagn. esp. nouv. de Moll. (Bull. de l'Acad. Brux. ix. 2, 1835), p. 12 ; Mal. Med. t. vi. f. 13.

- Lightning' Exp. St. 6.

'Porcupine' Exp. 1869 : 14, 89. 1870 : Atl. C.Sagres, 24, 27, 28, 28 a 30, 36; Med. 45, Capo di Gaeta, Adventure Bank. The specimens are young or mostly fragmentary; but many of them are 
fresh-looking, and all have evidently lived and died on the spots where they occurred.

Distribution. W. Norway (M. Sars, Asbjörnsen, Friele, Norman, and $J . G . J$. ), Cape Breton (de Folin), N. Spain ('Travailleur' Exp.), Mediterranean, Adriatic, and Madeira; 20-250 fms. Submarine Telegraph-Cable between Cagliari and Bona; 1100-1500 fms.?

Monodonta tinei, Calcara (1839), M. limbata, Philippi (1844), Trcchus bilabiatus, Phil. in Martini and Chemnitz ed. Küster (1846). Young and fry: T. horridus and Heliciella costellata, O. G. Costa. It will thus be seen that this remarkable and widely dispersed shell has been placed in five different genera, to which must be added Craspedotus of Philippi (1847) and Danilia of Brusina (1864). It is true that Olivia was proposed by Bertolini in 1810 for a genus of Polygastrica; but there is no probability of any confusion arising on that account, because these classes of the Invertebrata are so widely separated.

\section{Family VIII. TURBINIDA.}

1. Turbo Rugosus, L. S. N. p. 1234 : Chemn. Conch. Cab. v. t. 180. f. 1782-85; young (as T. calcar), f. 1786,7 .

'Porcupine' Exp. 1870 : Atl. St. 36 ; Med. Algesiras B., Benzert Road.

Distribution. Coasts of S.W. France and N. Spain, throughout the Mediterranean and Adriatic, Mogador, Madeira, and Cariaries; 0-80 fms., living in the littoral and laminarian zones.

Fossil. Miocene: Vienna Basin (Hörnes), Malaga (Duncan), Piedmont (Foresti). Pliocene: Italy and Rhodes. Post-tertiary : S. France and Tuscany.

Although this common Mediterranean shell has always been recognized and known as the $T$. rugosus of Linné, the only habitat given by him was "India ;" but he evidently was not acquainted with Mediterranean shells except from the works of other writers and from collections made by some of his pupils.

There are a few obsolete synonyms. The operculum is used for female ornament in Italy, and called " occhio di bue."

2. Turbo peloritanus, Cantraine.

T. peloritanus, Cantr. Diagn. de quelq. esp. nouv. de Moll. (1837), p. 11; Mal. Med. (1840), pl. vi. f. 22 .

'Porcupine' Exp. 1870 : Atl. St. 1, 2, 3a, 24-28a.

Distribution. Bay of Biscay ('Travailleur' Exp.), Mediterranean ('Washington' Exp.), G. Florida (Pourtales); 125-731 fms.

Fossil. Pliocene : Calabria and Sicily.

Trochus flosus, Philippi.

Var. carinata. Smaller, and usually having a single peripheral keel instead of several spiral ribs. Turbo carinatus, Cantr. loc. cit. f. 23 =Trochus glabratus, Phil. Not Trochus carinatus of Borson, a miocene fossil, which Hörnes placed in Turbo.

The body or animal is white. Young shells are umbilicate. 
Perhaps that character and the operculum having a multispiral nucleus on the underside may constitute sufficient grounds to separate the present species from Turbo; and in that case the genus might be called Cantrainea in honour of the discoverer and celebrated conchologist. I have had an opportunity of examining and comparing his species and its variety through the obliging attention of M. Van den Broeck.

Phasianella pulla, linné.

Turbo pullus, L. S. N. p. 1233.

P. pulla, B. C. iii. p. 338 , pl, viii. f. 1 ; v. p. 204 , pl. lxiv. f. 1 .

'Porcupine' Exp. 1870: At]. St. 8, 9, Vigo B., 26, Tangier B., Gibraltar. Young and dead shells, which were probably carried out by tidal or other currents from the littoral and sublittoral zones which this species usually inhabits. The greatest depth at which it has been noticed as living is 15 fathoms.

Distribution. From the Orkneys and Stornoway southwards to the Morea, Black Sea and Adriatic, Mogador, coast of Barbary, Madeira, Canaries, and Guadaloupe (Beau, fide Petit); 0-120 fms. Specimens from the greater and perhaps any depth beyond 15 fathoms may have been drifted.

Fossil. Pliocene : Antibes and Italy. Post-tertiary: N. Ireland and Nice.

Turbo pictus of Da Costa and several other unnecessary synonyms. Lamarck described it as Turbo pullus, and did not include it in his genus Phasianella. I regard $P$. intermedia of Scacchi and $P$. tenuis of Michaud as varieties of this common and therefore variable species. Very young specimens exhibit a small umbilical slit.

\section{Family IX. LitTorinidas.}

\section{Lacuna crassion, Montagu.}

Turbo crassior, Mont. Test. Brit. p. 309, t. 20 . f. 1.

L. crassior, B. C. iii. p. 344 ; v. pl. lxiv. f. 2.

'Porcupine' Exp. 1869 : St. L. Foyle, 33.

Distribution. Spitzbergen, White Sea, Russian Lapland, N. Pacific, Greenland, G. St. Lawrence, British coasts, and Etretat; 0-12 fms. Fossil. Post-tertiary: Belfast and Hull.

L. glacialis, Möller, L. vestita, Metzger, and perhaps Turbo pallidus, Donovan.

The characteristic canal is frequently wanting both in young and adult specimens of this species. Dr. Collingwood has always found it living and feeding on the polyparies of Alcyonidium hirsutum.

2. Lacuna divaricata, Fabricius.

Trochus divaricatus, Fabr. Fn. Grœnl. p. 392.

L. divaricata, B. C. iii. p. 346 , pl. viii. f. 2 ; v. p. 204 , pl. lxiv.f. 3 .

'Lightning' Exp. St. 4, 5, 7. Drifted.

'Porcupine' Exp. 1869: Donegal B.

Distribution. Arctic seas in both hemispheres, Iceland and Faroe 
Isles, Finmark to Gulf of Gascony, Algiers (Joly)!, Greenland to New York, Alaska to N. Japan ; 0-36 fms. Inhabits the laminarian zone.

Fossil. Pliocene?: Antibes.' Post-tertiary: Scandinavia and British Isles ; 0-1360 ft.

Variable and therefore polyonomatous. Among these names are Turbo vinctus, $T$. quadrifasciatus, and T. canalis of Montagu ; $\boldsymbol{L}$. solidula, L. labiosa, and L. frigida of Lovén; L. fabricii and L. arctica of Philippi ; L. fusca of Say ; and $L$. pertusa of Conrad. Brown made out of it four species of Phasianella, and Leach his genus Epheria.

3. Lacuna puteolus, Turton.

Turbo puteolus, Turt. Conch. Dict, p. 193, f. 90, 9I.

L. puteolus, B. C. jii. p. 348 ; v. p. 205 , pl. lxiv. f. 4 .

'Lightning' Exp. St. 4. Drifted.

Distribution. Greenland, Iceland, and Finmark to Vigo ; laminarian zone.

Fossil. Post-tertiary: Clyde beds, Portrush, Selsea and Dorset.

For the perplexing synonymy of this species I would refer to 'British Conchology.' It is connected with $L$, pallidula through Gould's $L$. neritoïdea, which I consider a variety of the latter species or an intermediate form.

1. Cithna tenella, Jeffreys.

Lacuna tenella, B. C. v. p. 204, pl. ci. f. 7 .

'Lightning' Exp. St. 5, 7.

- Porcupine' Exp. 1869: 4, 23, 23a, 36, 39-42. 1870: Atl. 1, 3, 6, 9, 16, 17, 17a, Setubal B., off C. Espichel, 22, 31-34; Med. $51,54,55$.

Distribution. Between the Hebrides and Faroes ('Triton' cruise), Bay of Biscay ('Travailleur' Exp.), many parts of the Mediterranean (Spratt, Nares, Monterosato, Italian and French Fxps.), between Gibraltar and the Azores ('Josephine' Exp.), Azores, Pernambuco, and E. of Japan ('Challenger' Exp.); 114-2050 fms.

Fossil. Pliocene: Calabria and Sicily (Seguenza). Post-tertiary : Greenock (Crosskey and Robertson)!

Var. costulata. More or less strongly striated lengthwise, especially on the upper whorls.

In the 'Annals \& Magazine of Natural History' for July 1870 I proposed the generic name Hela for this species; but I afterwards found not only that the name had been preoccupied so long ago as 1830 by von Münster in the Crustacen, but that the late $\mathrm{Mr}$. Arthur Adams had distinguished the same form of shell under the subgeneric title of Cithna in the Proceedings of the Zoological Society for 1863. His courtesy in sending me several species from Japan has satisfied me that they belong to the same genus as mine; and I therefore substitute Cithna for Hela as the generic name. It differs from Lacuna in being destitute of an epidermis, and in having instead of a flattened and channelled pillar an obliquely curved umbilical chink, which ends 
in a small but deep perforation and is enclosed by a more or less sharp and distinct ridge. The tentacles of the animal are ciliated as in Trochus and Rissoa, which is not the case in Lacuna. The shell varies in the comparative beight of the spire, as well as in the sculpture as shown in the variety costulata. That variety is Lacuna margaritifera of Watson.

\section{Cituna cincta ${ }^{1}$, Jeffreys. (Plate XX. fig. 8.)}

Shell globosely conical, thin, opaque, rather glossy : sculpture, a few and remote spiral striæ, of which there are from 3 to 6 on the last whorl and 1 or 2 on the penultimate and other whorls; the most prominent of these striæ is one below the suture, which gives the whorls a somewhat carinated appearance; this stria is minutely tubercled on the upper whorls : colour white: spire turreted, ending in a twisted point : whorls 5, swollen; the last exceeds two fifths of the whole shell, the others gradually enlarging: suture deep : mouth circular, bluntly angulated at the base : outer lip thin, slightly expanding, and folded over the pillar : inner lip attached to the pillar: umbilicus shallow, enclosed by a semicircular ridge and ending in a small but deep perforation. L. $0 \cdot 1$, B. $0 \cdot 1$.

'Porcupine' Exp. 1870 : Atl. St. 16. Two specimens.

3. Crthna carinata ${ }^{2}$, Jeffreys. (Plate XX. fig. 9.)

SHELL compactly pyramidal, thin, opaque, glossy : sculpture consisting of a single keel which surrounds the periphery or middle of each whorl and makes it angular; under the microscope the surface appears closely granular or fretted; the base is encircled by a few slight striæ : colour white, except as to the uppermost whorls, which are as in $C$. tenella yellowish-brown: spire turreted, ending in a symmetrical apex : whorls 5-6, angulated, flattened between the suture and the keel, regularly increasing in size : suture very deep : mouth quadrangular, sharply pointed at the base : outer lip thin, reflected behind: inner lip narrow, attached to the pillar : umbilicus saucer-shaped, enclosed by a slight and inconspicuous ridge and terminating in a small perforation. L. $0 \cdot 1$, B. $0 \cdot 1$.

'Porcupine' Exp. 1870 : Atl. St. 16. A single specimen.

4. Crthna Adamisi ${ }^{3}$, Jeffreys. (Plate XX. fig. 10.)

SHewx having the shape of a Helix, nearly globular, thin, semitransparent, and glossy : sculpture none except the umbilical ridge : colour white: spire rather short: whorls $4 \frac{1}{2}$, convex, the last occupying more than two thirds of the shell, and the others being in the same relative proportion; apex slightly twisted: suture very deep : mouth circular, bluntly pointed at the base : outer lip thin, folded partly over the umbilicus : inner lip adhering to the pillar : umbilicus small and narrow, enclosed by a sharp and nearly semicircular ridge; perforation scarcely perceptible. L. $0 \cdot 0625$, B. $0 \cdot 075$.

1 Encircled.

2 Keeled.

3 Named in honour of the memory of the late eminent malacologist Mr. Arthur Adams. 
'Porcupine' Exp. 1870 : Atl. St. 16, 17, 17a. Five specimens, more or less imperfect but characteristic.

5. Cithna natichformis ${ }^{\mathfrak{1}}$, Jeffreys. (Plate XX. fig. 11.)

SheLL obtusely triangular with an eccentric spire, thin, semitransparent, and glossy : sculpture, a few rather strong spiral striæ on the base or underside, besides the usual umbilical ridge : colour white ; spire very short: whorls 3 , convex, the last occupying three fourths of the shell; apex bulbous : suture very deep: mouth nearly circular, large and expanding: outer lip thin, angulated above: inner lip filmy: umbilicus large, enclosed by a sharp curved ridge or stria (sometimes by an outer and an inner stria), and ending in a small but deep perforation. L. $0 \cdot 075$, B. $0 \cdot 1125$.

'Porcupine' Exp. 1870: Atl. St. 17a. Three more or less imperfect specimens. This differs from the last species in shape, sculpture, shorter spire, and fewer whorls.

1. Littorina obtusata, Linné.

Turbo obtusata, L. S. N. p. 1232.

L. obtusatus, B. C. iii. p. 356 ; v. p. 205 , pl. Ixv. f. 1.

'Porcupine' Exp. 1869 : St. 9. Dead, and probably drifted by a current or voided by a fish.

Distribution. Yenissei G., Novaia Zemblia, White Sea, Iceland, Faroes, Finmark to Gibraltar, Mediterranean?, Azores (McAndrew), Davis Strait to New York; 0-15 fms. Living in the littoral and laminarian zones. The recorded localities in the Mediterravean are Toulon (Gay), S. France (Petit, fide Michaud), Malaga (McAndrew)!, Ajaccio (Requien), Corsica (Susini)!, and Sicily (Philippi, Bivona, Gemellaro, and others).

Fossil. Post-tertiary: Scandinavia, British Isles, S.W. France, and Canada ; $0-1360 \mathrm{ft}$.

Principal synonyms-Nerita littoralis, Linné, Turbo retusus, Lamarck, and Littorina arctica, Möller ; and as some of the varieties T. palliatus, Say, T. fabalis, Turton, and L. limata, Lovén.

Mr. Duprey found in Jersey a monstrous specimen which had 3 tentacles and 3 eyes. The middle tentacle was bifid; and the eye belonging to it was double and presented two small points in juxtaposition. The other eyes were simple or regular.

\section{Littorina Rudis, Maton.}

Turbo rudis, Mat. Nat. Hist. and Antiq. West. Counties, 1797, p. 277.

L. rudis, B. C. iii. p. 364 ; v. p. 206 , pl. lxv. f. $3,3 a, 3 b$.

' Lightning' Exp. St. 5. Probably drifted.

'Porcupine' Exp. 1869 : Donegal B., Lough Swilly. 1870: Atl. Vigo $\mathbf{B}$.

Distribution. Coasts of N. Atlantic on both sides, from Spitzbergen to Lisbon and Davis Strait to Staten I. in the U.S., Iceland, Van-

I Shaped like a Natica. 
couver I., N. Japan, White Sea, Azores, Algiers (J. W. Flower), Minorca (Cardona fide Hidalgo), Naples (Scacchi), Adriatic, and Black Sea; littoral. A dead specimen was dredged by Prof. G. O. Sars among the Loffoden Isles in 200-300 fathoms, and other dead specimens have been dredged elsewhere at considerable depths; but all of them were probably transported by tidal or marine currents.

Fossil. Pliocene: Norwich Crag. Post-tertiary: Scandinavia, British Isles, and Canada ; 0-1360 ft.

Turbo saxatilis of Olivi, 1792. This name has certainly precedence of rudis by five years; but the latter name was adopted by Lamarck and has been in general use and acceptation for nearly a century. I think therefore that it will not be expedient now to make the change. Among the synonyms of this variable species may be mentioned $T$.jugosus and $T$. tenebrosus of Montagu, $T$. obligatus and T. vestitus of Say, possibly T. purpureus of Risso, L. gronlandica of Bolten, and other synonyms of Fabricius, Gould, Philippi, Middendorff, Pfeiffer, Brown, Johnston, Menke, Bean, Adams, and Reeve. The oldest name by far is that of Lister (Nerita reticulatus \&c.); but it is not quite binomial.

3. Littorina litorea, Linné.

Turbo littoreus, L. S. N. p. 1232.

L. litorea, B. C. iii. p. 368 , pl. viii. f. 3 ; v. p. 206 , pl. lxv. f. 4. 'Porcupine' Exp. 1869 : St. Donegal B.

Distribution. White Sea, Faroes and Nordland to Lisbon, eastern coasts of N. America from Newfoundland to New England, many places in the Mediterranean and Adriatic but requiring identification ; sublittoral. As this common species, called in England the 'periwinkle,' is a favourite delicacy of sailors, the occasional occurrence of its shell in foreign parts may possibly be thus accounted for.

Fossil. Pliocene : Red and Norwich Crag. Post-tertiary: Scandinavia, British Isles, and S.W. France ; $0-1360 \mathrm{ft}$.

There are a few antiquated and obsolete synonyms, including Turbo ustulatus of Lamarck. L. squalida of Broderip and Sowerby from the arctic ocean, and $L$. grandis of Middendorff from the Sea of Okhotsk appear to be varieties; and $L$. mandschurica of von Schrenck is a dwarf and eroded form, like that from Southend which I noticed in vol. iii. p. 373 of 'British Conchology.'

Genus I'PHITUs', Jeffreys.

SheLL conical, covered with spiral rows of tubercles; the apex cónsists of a cylindrical process of several whorls, which is closely striated lengthwise; operculum horny, paucispiral with a lateral nucleas.

The unique and remarkable little shell which I am about to describe somewhat resembles in shape and sculpture a fossil of the Zanclean or Lower Pliocene formation at Messina which Professor Seguenza kindly sent me under the manuscript name of Gemmula asperata. But Gemmula of that author is a subgenus of Trochus,

${ }^{1}$ One of the Argonauts. 
typified by T. gemmulatus of Philippi ${ }^{1}$. The peculiar apex may be compared to the stiliform process of Ianthina and Stilifer; and there are several other genera, such as Cacum and Turritella, in which the embryonic spire, which had become useless for the occupancy of the mollusk, is decollated or plugged up. The present genus is allied to Fossarus.

Iphitus tuberatus ${ }^{2}$, Jeffreys. (Plate XX. fig. 12.)

Shetc forming a short cone, solid, opaque, of a dull hue : sculp. ture, spiral ridges covered with numerous minute tubercles or beads; there are four or five of these ridges on the last whorl, three on the penultimate, and two on the preceding whorl; the base is also encircled by fine spiral strix; the stiliform process had been broken off, but sufficient remains to show that it was closely striated lengthwise, as in the fossil species which I have noticed: colour white with a faint tinge of yellow: spire rather short: whorls 3 , besides the stiliform process; the last or body-whorl is three or four times the size of all the others put together; the point of the stiliform or cylindrical process in the fossil shell is slightly twisted and blunt: suture deep: mouth rounded, angulated above: outer lip sharp, scalloped by the spiral ridges, expanded and reflected at the base of the pillar; inner lip wanting or inconspicuous : umbilicus none: operculum yellowish-brown, having four or five volutions, the innermost being very small; these are crossed by curved and numerous strix in the line of growth, as in species of Littorina. L. $0 \cdot 075$, B. $0 \cdot 05$.

'Porcupine' Exp. 1870: Atl. St. 6. A single but living specimen.

SUMmary of The FOREgoing List.

\begin{tabular}{|c|c|c|}
\hline \multirow{3}{*}{$\begin{array}{l}\text { Families. } \\
\text { VI. SCISSURELLID } A \ldots \ldots \\
\text { VII. TROCHID } \ldots \ldots \ldots \ldots\end{array}$} & \multicolumn{2}{|c|}{ No. of species. } \\
\hline & SCISSURELLA & 3 \\
\hline & Möllerta . . . . . . . . & 2 \\
\hline & Cyclostrema $\ldots \ldots$ & 13 \\
\hline & Tharsis $\ldots \ldots \ldots \ldots$ & 1 \\
\hline & Ganesa $\ldots \ldots \ldots \ldots$ & 2 \\
\hline & Circulus.......... & 1 \\
\hline & Trochus . . . . . . . . & 32 \\
\hline & Oltivia $\ldots \ldots \ldots \ldots$ & 1 \\
\hline VIII. TURBINID $\approx \ldots \ldots \ldots \ldots$ & Turbo $\ldots \ldots \ldots \ldots$ & 2 \\
\hline & Phasianella $\ldots \ldots$ & 1 \\
\hline IX. LITTORINIDAE . . & Lacuna . . . . . . . & 3 \\
\hline & Cithena.......... & 5 \\
\hline & LitToRINa $\ldots \ldots \ldots$ & 3 \\
\hline & IPHITUs. . . . . . . . . & 1 \\
\hline & Total & $\overline{70}$ \\
\hline
\end{tabular}


EXPLANATION OF THE PLATES.

\section{Plate XIX.}

Fig. 1. Scissurella umbilicata, p. 88.

2. Cyclostrema tenerum, p. 91 .

3. valvatoüdes, p. 92.

4. - simile, p. 92 .

5. - affine, p. 92.

6. bithynoïdes, p. 93.

7. Tharsis romettensis, p. 93 .

8. Ganesa pruinosa, p. 94.

9. - nitidiuscula, p. 94.

Plate XX.

Fig. 1. Trochus fulgidus, p. 95.

2. - minutubus, p. 95.

3. - lominarum, p. 95.

4. - cancellatus, p. 96.

5. - cinctus, var. affinis, p. 98.

6. - euspira, p. 98 .

7. - delicatus, p. 101.

8. Cithna cincta, p. 111.

9. - carinata, p. 111.

10. - adamsi, p. 111.

11. naticiformis, p. 112.

12. Iphitus tuberatus, p. 114.

3. On a Species of Myzomela from the Island of Boeroe.

By Henry O. Forbes, F.Z.S.

[Received February 20, 1883.]

On a recent journey, unfortunately of very short duration, which I made in the island of Boeroe, one of the Ceram group, I was able to reach the but thrice previously visited lake of Wakolo lying in the very centre of the island. Here I was fortunate enough to obtain several specimens of a beautiful species of scarlet Myzomela, which I cannot identify with any of the species of which diagnoses have been given by Mr. W. A. Forbes in his paper in the P.Z.S. 1879 , pp. 256 et seqq. I did not meet with any specimens of this bird in the country passed through in our eight days' journey up to the lake. The natives say it does not occur near the coast. About the lake itself it seemed by no means uncommon, and was mostly to be found in the fields cultivated by the Aléfuros, but which they would not allow a stranger to enter. The women who went daily to fetch the produce of these fields, brought me large numbers of this bird alive tied together by a string, which they caught by smearing the trees with "gutta ;" consequently most of the specimens were in a condition unfit for preservation. By offering, however, a higher remuneration for good specimens, I obtained a few in very fair condition. All are males however : only one appears to be in full plumage; two are nearly so; and several are young birds.

The full-dress bird is entirely scarlet, the bases of the feathers 
being black; the wings, the tail, and the preocular spot are black; the upper wing-coverts are black with a scarlet band on the outer webs nearly in the middle, but not extending to the extremity of the feather; the inner margins of the remiges are white; the irides are rich brown; the edges of the lower maxilla yellow; tongue yellow; legs and feet yellowish green; soles yellow.

The young male is at first almost entirely greyish brown; the throat is pale grey; but quite below the maxilla and under the eyes the orange-red colour indicates the coming scarlet; the back is greyish brown, but of a deeper colour in the uropygial region; the wings and the tail are brownish grey; the breast and under tailcoverts greenish fulvous; the margins of the upper wing-coverts pale fawn-colour with, in some lights, reflections of red; the margins of the remiges are olive-grey; the throat, the front of the head, the breast, and the uropygial region are the first to assume the scarlet colour of the adult; the angle of the wing has a dirty-white spot, which, with the olive-grey margins of the remiges, are the last to change to black.

The description of M.pusilla, as given on page 276 of the P.Z.S. for 1879 by $\mathrm{Mr}$. W. A. Forbes, might apply to the bird under remark; but as I have access to no library here, and have no specimens with which to compare my skins, I have not the means of satisfactorily determining them. Should this turn ont to be a new species, it might bear the name of Mrzomela waKoloensis.

At all events I am happy in being able to extend our knowledge of the distribution of this lovely genus to the Ceram group.

Amboina, December 15, 1882.

\section{On the Geckos of New Caledonia. By G. A. Bovlenger, F.Z.S.}

[Received February 26, 1883i]

\section{(Plates XXI. \& XXII.)}

The object of this paper is to serve as a guide to the identification of the Geckonidæ of New Caledonia, and to put order into their synonymy. As may be seen from the following bibliographical list, a good deal has been written on the subject before; but, in their endeavours to identify the species described by them with those described by M. Bavay, the subsequent authors have in many cases added to the confusion. Having, through the kindness of Messrs. Bavay, Barboza du Bocage, and Sauvage, enjoyed the advantage of studying the typical specimens described by those gentlemen, which seemed to require reexamination, I have arrived at such results as will be of some use to the student of the New-Caledonian fauna and to herpetologists generally; for a glance at the synonymies of the species will show how great was the confusion. Without bringing together and comparing carefully the typical specimens in the museums of 